Research Report No. 29/2011

\title{
Puzzling About State Excuses as an Instance of Group Excuses
}

François Tanguay-Renaud

Osgoode Hall Law School of York University, FTanguay-Renaud@osgoode.yorku.ca

Follow this and additional works at: http:// digitalcommons.osgoode.yorku.ca/clpe

\section{Recommended Citation}

Tanguay-Renaud, François, "Puzzling About State Excuses as an Instance of Group Excuses" (2011). Comparative Research in Law \& Political Economy. Research Paper No. 29/2011.

http://digitalcommons.osgoode.yorku.ca/clpe/67 


\section{OSGOODE}

OSGOODE HALL LAW SCHOOL

YOR K UN I VERS I T Y

\section{OSGOODE HALL LAW SCHOOL}

Comparative Research in Law \& Political Economy

RESEARCH PAPER SERIES

Research Paper No. 29/2011

\section{Puzzling about State Excuses as an Instance of Group Excuses}

François Tanguay-Renaud

Editors:

Peer Zumbansen (Osgoode Hall Law School, Toronto, Director Comparative Research in Law and Political Economy)

John W. Cioffi (University of California at Riverside)

Leeanne Footman (Osgoode Hall Law School, Toronto, Production Editor)

Comparative Research in Law \& Political Economy 


\title{
OSGOODE
}

OSGOODE HALL LAW SCHOOL YOR K U NIVERSITY

\section{OSGOODE HALL LAW SCHOOL}

\section{Comparative Research in Law \& Political Economy}

\section{Puzzling about State Excuses as an Instance of Group Excuses}

\begin{abstract}
:
Can the state, as opposed to its individual human members in their personal capacity, intelligibly seek to avoid blame for unjustified wrongdoing by invoking excuses (as opposed to justifications)? Insofar as it can, should such claims ever be given moral and legal recognition? While a number of theorists have denied it in passing, the question remains radically under-explored.
\end{abstract}

In this article (in its penultimate draft version), I seek to identify the main metaphysical and moral objections to state excuses, and begin to investigate their strength. I work from the ecumenical assumption that general understandings of modern states as group moral agents proper or as mere fictional points of imputation for individual behavior are both plausible, and that the question of state excuses should be asked in terms of both paradigms. Issues addressed include: the lack of state consciousness/affect, the nature and relevance of developmental and executive defects in group agents, the value of state interests and how interests relate to plausible claims of excuses, the shortfall of responsibility argument for group responsibility and its interface with state excuses, the symbolic and consequential (dis)value that state excuses may have, as well as concerns that states are entities that should live up to outstandingly high virtuous standards of impartiality and equanimity.

I conclude that even if the range of excuses available to states does not overlap neatly with excuses available to ordinary individuals, some excuses may still be morally available to states. More generally, I emphasize the need for a systematic discussion of group excuses writ large, and of their relationship with the wider question of when group entities may legitimately be singled out to bear adverse normative consequences for wrongdoing.

\section{Keywords:}

excuses, justifications, state, group, collective, corporate agency, responsibility, fictions of agency and responsibility, group consciousness, affect, constitutional disorders, state interests, shortfall of responsibility, symbolic and consequential value, state impartiality, virtue, Pettit 
Draft for posting to SSRN

Forthcoming in RA Duff, L Farmer, S Marshall, and Victor Tadros (eds.), The Constitutional of Criminal Law (Oxford: Oxford University Press).

\title{
PUZZLING ABOUT STATE EXCUSES AS AN INSTANCE OF GROUP EXCUSES
}

\author{
François Tanguay-Renaud*
}

\section{A. Why Reflect upon State Excuses \& How I Intend to Do So}

Can the state, as opposed to its individual human members in their personal capacity, intelligibly seek to avoid blame for unjustified wrongdoing by invoking duress, provocation, a reasonable mistake in justification, or other types of excuses? Insofar as it can, should such claims ever be given moral and legal recognition? It is certainly not uncommon to encounter offhand statements to the effect that at least some state excuses are both conceivable and legitimate. ${ }^{1}$ Yet, the issue has yet to receive the sustained philosophical attention it deserves. Few theorists speak to it specifically, and those who do typically discard rather rashly the possibility of genuine state excuses. This theoretical neglect is symptomatic of a more general lack of analytical attention to the conditions that must obtain for the state to be legitimately held responsible for wrongdoing in law and morality. In this chapter, my aim is to start filling this gap by mapping out the topic of state excuses in a way that will, hopefully, spur a more systematic discussion of its various facets,

*Assistant Professor at Osgoode Hall Law School, and Member of the Graduate Faculty of the Department of Philosophy, York University, Toronto. I would like to thank Antony Duff, Timothy Endicott, John Gardner, Stuart P. Green, Philip Pettit, Andrew Simester, Walter Sinnott-Armstrong, Victor Tadros, and Ekow Yankah for constructive discussions, comments, and criticisms. Special thanks are also owed to the participants in the two workshops that led to the production of this volume, the Oxford Jurisprudence Discussion Group, as well as the 2011 York University Graduate Student Philosophy conference where this paper was presented as a keynote address.

${ }^{1}$ For example, in his recent book on The Constitutional State (Oxford: Oxford University Press, 2010) 131, NW Barber writes that 'A state which enters into an unjust war in a climate of moral panic is, all other things being equal, less reprehensible than a state which enters into that same war whilst fully aware of its injustice'. For an argument assuming the availability of at least some excuses for domestic state wrongdoing, see eg T Sorell, 'Morality and Emergency' (2003) 103 Proceedings of the Aristotelian Society 21, 33-34. 
including its relationship with the wider question of when the state may legitimately be singled out to bear adverse normative consequences for wrongdoing. I say that my aim is limited to 'mapping out' the topic because I believe that an important first step in understanding state excuses is to identify properly the many complex and controversial theoretical puzzles they raise.

In a bid to remain ecumenical, I will adopt a wide understanding of excuses that comprises the core pleas which, for right or for wrong, have sometimes been treated as excuses in recent theoretical debates about individual responsibility in morality and law. By that, I mean claims that although a given course of conduct was, all things considered, wrong, it was not blameworthy - or was less blameworthy, in the case of a partial excuse - because it was (1) 'justified' or 'warranted' from the epistemic perspective of the actor, (2) reasonably motivated by reasonable emotions or other understandable cognitive or affective attitudes, (3) nonresponsible, or (4) a hybrid of two or more of these claims. Of course, there are important differences between these four types of claims. In fact, some think of these differences as being so salient that they exclude the first type of claim from the category of excuses altogether and reclassify it as justificatory. Others, who argue that excuses are primarily reasonsbased and responsibility-affirming, would differentiate the third type of claim, and perhaps some instances of the fourth, as claims of 'exemption' from responsibility or 'denial of responsibility' simpliciter. While these reclassifications often track deep and important dissimilarities, ${ }^{2}$ they remain contentious. Given the exploratory nature of my project, I avoid pre-empting meaningful discussion of any possible state excuses by assuming that restrictive views such as these can simply be transposed, without argument, onto the domain of state responsibility.

Claims of state justification tend not to elicit the same amount of suspicion as claims of state excuses. For example, arguments about the justification of state coercion, state punishment, and state-led warfare

\footnotetext{
${ }^{2}$ I emphasize some of them in relation to individual excuses in $\mathrm{F}$ Tanguay-Renaud, 'Individual Emergencies and the Rule of Criminal Law' in F Tanguay-Renaud and J Stribopoulos (eds), Rethinking Criminal Law Theory: New Canadian Perspectives in the Philosophy of Domestic, Transnational, and International Criminal Law (Oxford: Hart Publishing, 2012) 21.
} 
pervade moral, political, and legal philosophy. Yet, it is not unusual to find moral and criminal law theorists who, like Andrew Simester, maintain that excuses 'are simply inapplicable to artificial actors such as the state., ${ }^{3}$ This assumption is also deeply entrenched in other legal fields concerned with the regulation of state wrongdoing. For example, Alan Brudner writes that, while they may be justified in infringing rights, 'States cannot be constitutionally excused for violating rights'.

Such brisk rejections of state excuses are intriguing, especially given the fact that the law of several oft-theorized jurisdictions provides for blame and even punishment of the state and state organs for wrongdoing. For example, the Criminal Code of Canada makes clear that 'municipalities' and other 'public bodies' may, like private organizations, be held responsible and punished for criminal wrongdoing. ${ }^{5}$ In the context of some civil actions, public authorities may also be subjected to punitive damages. ${ }^{6}$ The constitutional context is no exception. Admittedly, constitutional law continues to be primarily understood in terms of the regulation of the legal validity of exercises of state powers, rather than in terms of the regulation of state wrongdoing, as evidenced by the remedies usually granted for rights violations - that is, legal invalidity and procedural remedies such as exclusion of evidence or stay of proceedings. That being said, state constitutional wrongdoing is regularly condemned and may even be punished. For example, punitive damages are sometimes

\footnotetext{
${ }^{3}$ AP Simester, 'Necessity, Torture and the Rule of Law' in VV Ramraj (ed), Emergencies and the Limits of Legality (Cambridge: Cambridge University Press, 2008) 289, 300.

4 A Brudner, 'Excusing Necessity and Terror: What Criminal Law Can Teach Constitutional Law' (2009) 3 Crim L and Philosophy 147, 148 (Emphasis in the original).

${ }^{5}$ Criminal Code RSC 1985 c C-46, ss 2, 22.1, 22.2. Here, Canada is not alone. See eg SP Green, 'The Criminal Prosecution of Local Governments' (1994) 72 North Carolina L Rev 1197 and N Kyoto, 'Criminal Liability of Corporations - Japan' in H de Doelder and K Tiedemann (eds), Criminal Liability of Corporations (The Hague: Kluwer, 1996) 275, 283. Other jurisdictions are more hostile to holding state bodies criminally responsible. Consider, for example, France (Code pénal, s 121-2) and the Netherlands (see R de Lange, 'Political and Criminal Responsibility' (2002) 6(4) Electronic J of Comparative L s $7<$ http://www.ejcl.org/64/art64-18.html >).
}

${ }^{6}$ See eg Criminal Liability and Proceedings Act RSC 1985 c C-50, ss 17-18 (Canada). 
deemed an 'appropriate and just remedy' for egregiously unjustified violations of rights under s. 24(1) of the Canadian Charter of Rights and Freedoms. ${ }^{7}$ At the level of international law, the possibility of criminally censuring and punishing states for wrongdoing has often been contemplated and defended over the years, even if the legal status of 'international crimes of state' remains uncertain. ${ }^{8} \mathrm{Be}$ that as it may, condemnation of state behaviour in United Nations resolutions, as well as through diplomatic channels, is a commonplace. Last but not least, popular and political indictments of states and state bodies as 'wrongdoers' or 'criminal' abound, as do philosophers' characterizations of such entities as moral agents susceptible of moral censure for wrongful deeds. ${ }^{9}$

Of course, the questions of whether and how the state may legitimately be blamed or punished for wrongdoing, as well as what understandings of 'the state' render such inquiries intelligible, require

\footnotetext{
${ }^{7}$ See eg Crossman v The Queen (1984) 9 DLR $\left(4^{\text {th }}\right) 588$ (Federal Court, Trial Division); Patenaude v Roy (1988), 46 CCLT 173 (Superior Court of Quebec); Freeman v West Vancouver (District) (1991), 24 ACWS (3d) 936 (Supreme Court of British Columbia).

${ }^{8}$ The concept of state responsibility for international crimes gained support following the First World War, but was pushed back into the background by the development of the principle of individual criminal responsibility under international law after the Second World War. For an argument that international crimes of state are currently on the threshold between lex ferenda and lex lata, see NHB Jørgensen, The Responsibility of States for International Crimes (Oxford: Oxford University Press, 2000). For a forceful defense of the intelligibility and legitimacy of state criminalization in international law, see D Luban, 'State Criminality and the Ambition of International Criminal Law' in T Isaacs and R Vernon (eds), Accountability for Collective Wrongdoing (Cambridge: Cambridge University Press, 2011) 61.

${ }^{9}$ In respect of the state considered as a whole, recall Hannah Arendt's writings on the acts of Adolf Eichmann: 'crimes of this kind were and could only be, committed under a criminal law and by a criminal state.' H Arendt, Eichmann in Jerusalem: A Report on the Banality of Evil (New York: Viking Press, 1963) 240. Consider also claims, like John Gardner's, that 'States are moral agents too... The state must not murder or be complicit in murder. It must not rape or be complicit in rape. It must not rob or be complicit in robbery...The state is also bound, even in its exercises of authority and its uses of coercion, by the general principles of morality that bind us all.' J Gardner, 'Prohibiting Immoralities' (2006) 28 Cardozo L Rev 2613, 2628.
} 
further investigation in their own right. ${ }^{10}$ In this chapter, though, I start with the assumption that at least some of the practices of blame and punishment listed above are legitimate and target entities which detractors of state excuses would, or should, themselves readily incorporate in their understanding of the state.

The question then becomes what reasons there may be for thinking that exculpatory claims of excuses - as opposed to, say, claims of justification-are unavailable to the state and, thus, should not be recognized. First, it bears acknowledging that some do not share my working assumption, and believe that whatever the state does is necessarily justified. Therefore, they argue, the question of state excuses never arises. This position finds both moral and legal instantiations. At the moral level, some equate the state with the justified pursuit of the public interest and characterize as private, or non-state, any actions that depart from it. At the legal level, the argument tends to be that the state is no more and no less than a (domestic) legal system, such that no deed can be attributed to it at the domestic level unless that deed is legally authorized or permitted in some way - for example, through the recognition of a legal justification. Such challenges to the intelligibility of unjustified state wrongdoing and, thus, to the possibility of state excuses are, in my view, exceedingly myopic. As I argue elsewhere, they fail to give sufficient consideration to the complexity of what many modern states' socio-legal constitutions enable them to do, sometimes in defiance of morality or extralegally. They also fail to give adequate attention to existing practices of moral and legal censure for behaviour that can be said, to some meaningful extent, to be organizationally programmed by the state. ${ }^{11}$ What is more, they tend to ride roughshod over many important puzzles related to what specific justifications should be afforded (or not) to the state for prima facie wrongdoing. Thus, I mostly disregard such contentions here.

\footnotetext{
${ }^{10} \mathrm{I}$ seek to make some progress in addressing these underexplored questions in $\mathrm{F}$ Tanguay-Renaud, 'Criminalizing the State' (2012) Crim L and Philosophy (forthcoming).

11 See ibid, as well as F Tanguay-Renaud, 'The Intelligibility of Extralegal State Action: A General Lesson for Debates on Public Emergencies and Legality' (2010) 16 Legal Theory 161 .
} 
I say 'mostly,' because there may still be a methodological lesson to be drawn from such challenges. As I suggested above, even if we accept that unjustified state wrongdoing is intelligible, there remains an important debate to be had about how it can best be explained. Should we think of states, and state bodies or institutions, as real and irreducible moral agents who, like individual human agents, can perpetrate wrongs and, possibly, also claim excuses for themselves? Or should we instead concede that wrongdoing states are no more than fictions to which the conduct, wrongs, blameworthiness and, perhaps, excuses of certain human agents may legitimately be attributed? This controversy about the nature of the state and state responsibility is not new in moral and legal theory circles, and parallels in many ways debates about the responsibility of organizations more generally. ${ }^{12}$ As I indicated earlier, I cannot get to the bottom of this controversy here. Yet, I can also not ignore it completely, given its undeniable relevance to the question of whether and how we should think of state excuses. Therefore, in sections B and C below, I will appraise the plausibility of state claims of excuses in terms of both of these leading paradigms, and suggest that some such claims are indeed consistent with both. Note, however, that since excuses, as I understand them, are primarily rebuttals of blameworthiness, since the core case of blame is blame that has a blameworthy moral agent as its direct object, and since the attribution of blameworthiness to, and blaming of, a posited fiction is at best a non-standard case, ${ }^{13}$ I will consider the realist paradigm first, and the fiction paradigm second. Note further that, in both cases, I will primarily focus on the possibility of state excuses in morality. While my arguments will also often bear directly on the possibility of state excuses in law, and while I will sometimes even explicitly discuss legal excuses, I

\footnotetext{
12 For a useful survey of such general debates, see P Cane, Responsibility in Law and Morality (Oxford: Hart Publishing, 2002) 143-171.

${ }^{13}$ I take this understanding of the core case of blame and blameworthiness to be broadly accepted amongst theorists, irrespective of whether they consider blame to be primarily an evaluative, punitive, or relations-adjusting practice. See eg TM Scanlon, Moral Dimensions: Permissibility, Meaning, Blame (Cambridge, Mass: Belknap Press, 2008) 128, 160-166; J Gardner, Offences and Defences: Selected Essays in the Philosophy of Criminal Law (Oxford: Oxford University Press, 2007) 227; G Sher, In Praise of Blame (Oxford: Oxford University Press, 2006) 114; J Glover, Responsibility (London: Routledge and Kegan Paul, 1970) 44.
} 
wish to leave open for further consideration the question of whether moral excuses should always be given legal effect.

With such caveats in mind, let me ask again: assuming that wrongdoing can be attributed to the state in some way or the other, and that the state can be morally, criminally, constitutionally, or internationally blamed and, perhaps even, punished for it, why should excuses be unavailable to it? Objections are typically of two kinds. Some are metaphysical. They rest on the assumption that excuses reflect profoundly human characteristics and are, therefore, unavailable to organizations such as states and institutional state bodies. Other objections are moral and hold that, even if the state and its institutional organs are entities that can invoke excuses, such claims should not be recognized given the moral position of the state. In what follows, I discuss objections of both kinds.

It is worth noting, at this stage, that many objections of the first type, and perhaps also some of the second, may be aimed at organizations more generally, and not only at the state and its corporate organs. Accordingly, my inquiry will also be of relevance to the question of whether organizations, considered as a class, can intelligibly and legitimately make excuses. ${ }^{14}$ I choose to focus on the state, however, out of concern that organizations such as private companies with more restricted constitutional aims and purposes and more constrained means of action may not as persuasively or generally be subject to blame qua irreducible agents - the first paradigm to be investigated. ${ }^{15} \mathrm{I}$ am also of the

\footnotetext{
${ }^{14}$ The question of the availability of excuses to non-state organizations, such as private corporations, is also notoriously under-theorized. Some theorists assume that corporations can simply 'mak[e] use of any available general excuses'. See J Horder, Excusing Crime (Oxford: Oxford University Press, 2004) 262. However, most leading theorists of corporate responsibility simply ignore the topic altogether. See eg C Wells, Corporations and Criminal Responsibility (Oxford: Oxford University Press, 2001); B Fisse and $\mathrm{J}$ Braithwaite, Corporations, Crime and Accountability (Cambridge: Cambridge University Press, 1993). Such broad-brush approaches are manifestly unsatisfactory given, on the one hand, the existence of widespread regimes of corporate criminal liability that beg the question of the availability of excuses to corporations and, on the other, the many objections of the types leveled against state excuses that extend to corporate excuses generally.

15 Part of my concern is shared by TM Scanlon, who writes that 'The possibility of blaming collective agents seems clearest when one moves away from entities such as
} 
view that state excuses call for a discussion of further interesting moral objections that do not apply, or do not apply with the same force, to other organizations. That said, it is my hope that, insofar as my analysis is applicable to other organizations, the reader will be inclined to employ it, mutatis mutandis, to elucidate the intelligibility and legitimacy of their excuses.

\section{B. ExCusing the State QUA IrReducible Moral Agent?}

\section{Philip Pettit's Model of Corporate/State Agency}

An increasing number of contemporary theorists conceive of the state as a kind of corporate (group, collective-I use these terms as synonyms) organization that can itself be a moral agent. How can this be if, according to the time-honoured objection, corporate organizations have no discernible bodies or minds of their own? The argument tends to rest on the assumption that some groups of interacting human beings can be relatively autonomous agents - that is, that they can form action-directing attitudes such as intentions, develop plans, and perform concerted actions, that cannot be fully reduced to those of their members - thanks at least in part to the operation of a normative framework. Modern states, which are made-up of various institutional organs themselves reliant on the agency of countless individuals whose identity changes over time, ${ }^{16}$ are often thought to fall in this category, alongside other similarly integrated corporate bodies. These states all have a constitution that constitutes and divides labour between their various organs, lays out principles of governance, and institutes authoritative decision-making, control, and review mechanisms. By jointly committing and adhering to this

soap companies to collective agents that purport to be guided by noncommercial aims, and when one considers blame by individuals whose relation to these agents is something closer than that of consumer and producer.' Scanlon, Moral Dimensions (n 13) 165.

${ }^{16}$ What individuals are comprised in the corporate organization of the state can be a matter of controversy. John Rawls picks up on one aspect of this debate when he distinguishes between 'states, as traditionally conceived' and 'liberal democratic peoples (and decent peoples).' While the latter necessarily include ordinary citizens in the organizational unit of evaluation, the former may not. J Rawls, The Law of Peoples (Cambridge, Mass: Harvard University Press, 1999) 23-30. 
constitution to a reasonable extent, individual members allow their state qua corporate entity to form judgments and exhibit attitudes as a coherent whole, and to make reasonably consistent decisions over time on the evaluative propositions (including moral and legal reasons) that they present to it for consideration. Individual members also enable their state to execute its decisions by complying with constitutionally-adopted action plans — in the form of rules, practices, directives, and commands — devised to implement them.

The thought, then, is that modern states often have what it takes to be moral agents proper. Like other moral agents, they are regularly confronted with normatively significant choices, involving the possibility of doing right or wrong. Through the intercession of their individual members, they may also have the understanding and access to evidence necessary for making normative judgments about these choices, as well as the capacity to implement them in the world. Crucially, though, as I imply above, if they are to count as moral agents in their own right, states qua corporate organizations must also have the required control over the said judgments. That is, they must be able to judge and plan for action in ways that are irreducible to the judgments and plans of other agents, including those of their members. To see how this is possible, Philip Pettit's recent account of group agency is most helpful. Pettit's account remains one of, if not the, most careful and sophisticated account of irreducible group agency to date, and it is also one of the only such accounts to be quite transparently applicable to complex groups like states. ${ }^{17}$ As a result, I use

${ }^{17}$ See especially P Pettit, 'Responsibility Incorporated' (2007) 117 Ethics 171, and P Pettit, 'The Reality of Group Agents' in C Mantzavinos (ed), Philosophy of the Social Sciences: Philosophical Theory and Scientific Practice (Cambridge: Cambridge University Press, 2009) 67, 89. It is important to acknowledge that many of Pettit's insights were developed in collaboration with Christian List, as made clear in their recent comprehensive restatement of the argument in C List and P Pettit, Group Agency: The Possibility, Design, and Status of Corporate Agents (Oxford: Oxford University Press, 2011). However, since the separate articles on which I rely most were authored by Pettit himself, I keep referring to him alone, as a shorthand. See also other generally less developed accounts along similar veins in D Copp, 'On the Agency of Certain Collective Entities: An Argument from "Normative Autonomy" in P French and HK Wettstein (eds), Midwest Studies in Philosophy: Shared Intentions and Collective Responsibility, vol XXX (Boston: Blackwell Publishing, 2006) 194; M Gilbert, Sociality and Responsibility: New Essays in Plural Subject Theory (Lanham, Md: Rowman and Littlefield, 2000) ch 8; O O'Neill, 'Who Can Endeavour Peace?' in D Copp (ed), Nuclear 
it as the main backdrop for my analysis, with the hope that most of the general insights I derive from its scrutiny will hold even if specific aspects of the account end up being refuted in future arguments.

Pettit argues that groups whose judgments depend on the judgments of more than one individual can be agents insofar as they respond rationally to their environment on a reasonably consistent basis. Constitutions facilitate group agency by assigning decisional roles to the group's members and setting limits on what they can and cannot do. To the extent that the group's constitution provides sufficient constraints against internal inconsistencies, the group operating under it may then be a relatively autonomous agent over time (despite deriving all its matter and energy from its individual human members). Pettit argues that constitutional constraints are sufficient for a group to be autonomous in this sense when they ensure that, under normal conditions, reason is 'collectivized,' such that majority views do not always prevail and the group's attitudes cannot be described as a simple majoritarian function of the members' attitudes. In Pettit's own words: 'Autonomy is intuitively guaranteed by the fact that on one or more issues the judgment of the group will have to be functionally independent of the corresponding member judgments, so that its intentional attitudes as a whole are more saliently unified by being, precisely, the attitudes of the group. ${ }^{18} \mathrm{He}$ also insists that decision procedures must be in place to guarantee that the group can change and correct its irreducible attitudes over time, so as to

Weapons, Deterrence, and Disarmament (Canadian Journal of Philosophy, vol 12, Calgary: University of Calgary Press, 1986) 41; P French, Collective and Corporate Responsibility (New York: Columbia University Press, 1984).

${ }^{18}$ Pettit, 'Responsibility Incorporated' (n 17) 184. Pettit claims that a central case of such group autonomy obtains when the group's constitution effectively requires members to aggregate their judgments on individual premises of decisions, rather than their final judgments on overall decisions in a simple majoritarian way. He also allows for other suitable decisional arrangements, including more complex 'distributed premise-based procedures' where different subgroups specialize on judging specific premises. These conclusions come out primarily of Pettit's treatment of the well-known discursive dilemma. See eg C List and P Pettit, 'Group Agency and Supervenience' in J Hohwy and J Kallestrup (eds), Being Reduced: New Essays on Reduction, Explanation, and Causation (New York: Oxford University Press, 2008) 75. 
ensure the minimal rational coherence and integrity that we expect of agents proper.

The claim, then, is that state constitutions often ensure such relative state autonomy and minimal diachronic rational coherence and integrity by imposing a variety of balances and checks on state decisionmaking - for example, separation of powers, federal division of powers, judicial review of administrative and legislative action, stare decisis, elections, impeachment procedures, and so forth. Depending on how they are constituted, discrete institutional state organs pertaining to the executive, legislative, or judicial branch-sometimes at both federal and state, or provincial, levels - can also be imbued with such relatively autonomous agency. Commonly-discussed examples include municipalities, public corporations, the army, provincial governments, various administrative agencies, as well as the executive as a whole. ${ }^{19}$ When such suitably-constituted group organizations arrange for moral or legal wrongs to be perpetrated, given the decisions they license and the constitution by which they channel those decisions, they are fit to be held responsible and, possibly, blamed for them qua irreducible 'source of the deed.'

Focusing on the state as whole for the sake of simplicity, one may interject here that, even if this account is sound in respect of developed liberal democratic states, other states may not be sufficiently well organized to respond rationally to their environment on a consistent basis qua irreducible corporate agents. How should we think of such states? Are they states to which a plea of insanity, mental disorder, or straight-out non-responsibility should be available against allegations of wrongdoing? I am tempted to answer with a qualified yes. To the extent that they do not have a sufficiently well-developed constitutional apparatus, or that their individual members do not commit to and comply with it enough, such states do not qualify as relatively autonomous moral agents capable of acting contrary to reason and answering to it. At best, they may be

${ }^{19}$ Even if such state organs obviously do not constitute 'the state' as a whole, they typically form significant parts of it, such that consideration of their agency and possible excuses seems to dovetail with a discussion of state excuses. An explanation of the precise nature of their connection to 'the state'-be it legal, conventional, functional, or otherwise-is outside the ambit of this chapter. 
deficiently-constituted 'quasi-states,' whose decisions and actions are, in general, reducible to the decisions and actions of some of their individual members. At worse, they are utterly disorganized 'failed states' that possess almost none of the characteristics of what we normally conceive as states. $^{20}$

Here, one may think, lies the main difference with cases of individual insanity or mental disorder. Even when mentally-disordered individuals are thoroughly incapable of responding to reason, they, unlike quasi-states or failed states, remain embodied, identifiable and, in a sense, irreducible entities. Some may also argue that, as mentally disordered as they may be, human beings are deserving of a kind of respect and dignity that is not necessarily warranted, or warranted in the same way, in the case of degenerate forms of human organization like failed and quasi-states. There is certainly some truth to this line of argument. However, I still think the analogy between individual and state insanity can be preserved to a meaningful extent if we insist that failed and quasi-states can remain identifiable in some respects - say, territorially and in the eyes of certain relevant national and international actors - and that, like the mentally disordered, they might, in some possible world, be 'cured' or re-organized in a way that makes state agency possible. For example, it is conceivable that, through its own resources and international assistance, the failed state of Somalia (as we know it today) could one day develop out of its debilitating predicament. Thus circumscribed, the analogy would also seem to be applicable to identifiable institutional state organs and other sub-state corporate entities that lack irreducible agency, yet are susceptible of reorganization that would make it possible.

Unfortunately, this stretched analogy is only the beginning of our troubles. The next and more difficult question is whether a model of irreducible state agency such as Pettit's can be consistent with claims of excuses that extend beyond claims of complete lack of responsibility.

${ }^{20}$ I borrow this distinction from $\mathrm{T}$ Erskine, 'Assigning Responsibilities to Institutional Moral Agents: The Case of States and "Quasi-States" in Can Institutions Have Responsibilities?: Collective Agency and International Relations (New York: Palgrave MacMillan, 2003) 19, 29-31. 


\section{The Challenge of Affect-Based Excuses with a Cognitive Twist}

It is sometimes objected that many common individual excuses are grounded in conscious phenomenal experiences such as affective experiences and that, since states and corporate state bodies do not have such experiences of their own, they simply cannot claim these excuses. Consider the excuse of duress, which Andrew Simester, who champions this objection, explains in the following terms:

Suppose, for example, that $\mathrm{D}$ attacks and seriously injures $\mathrm{V}$ because $\mathrm{T}$ threatens otherwise to kill her. Notwithstanding that it was impermissible for $\mathrm{D}$ to act as she did, in the sense that there were insufficient valid reasons for her conduct, we may be reluctant to fault D. Our reluctance is because, although D's reason for acting was (objectively speaking) inadequate, we can understand that it was good enough for D. She feared for her life. Any reasonable person might have been impelled by such a fear; where this is so, we cannot make the inference of culpability that would normally entitle us to blame D for her actions. In such cases, we may allow for an excuse. ${ }^{21}$

This affect-based account of the excuse of duress is generally accepted and, arguendo, I shall assume its soundness. ${ }^{22}$ Simester's objection is that, since corporate organizations such as the state cannot experience the fear that is necessary to ground this excuse, it is not available to them. No doubt, their individual members can experience the required fear, and may

${ }^{21}$ Simester, 'Necessity, Torture, and the Rule of Law' (n 3) 299.

${ }^{22}$ For example, Jeremy Horder writes that 'All duress cases calling for an excuse have at least one ascriptive aspect [...] The great phenomenological strength of D's fear must alter the balance of reasons in D's mind, so that he or she understandably gives priority to saving him- or herself, if need be by committing the wrong in question.' Horder, Excusing Crime (n 14) 58. See also Gardner, Offences and Defences (n 13) 110, 138, 258. There are theorists who think that, in the end, all sound excuses - including all forms of duress - are grounded in cognitive errors of perception. See eg P Westen, 'An Attitudinal Theory of Excuse' (2006) 25 L and Philosophy 289. I find such arguments unpersuasive given that some people who are perfectly aware of the wrongfulness of their deeds when acting under duress may still deserve to be excused if their fear was reasonable and sufficient to explain their actions (assuming an acceptable level of self-control). 
sometimes be excused for their wrongdoing on that basis, but states and state bodies qua irreducible corporate agents cannot.

I could not hope to do justice here to the deep and complex metaphysical question of whether corporate entities like states and state bodies can have affective experiences and other conscious phenomenal states of their own. However, some general remarks seem apposite. If functionalist thinkers like Pettit are right about corporate agency, then given some plausible empirical claims about states - that they have decision-making mechanisms, that their decisions can have reasonable coherence over time, etc.- - there seems to be no principled difficulty in ascribing genuine and irreducible cognitive states to them. According to such a view, states and other appropriately constituted corporate entities can quite literally make judgments, acquire beliefs about what they judge to be the case, intend actions, and so forth. However, the case for corporate affective states and other phenomenal experiences is more difficult to make.

Admittedly, there may be emotions, like anger, that arise among group members (who, by hypothesis, are otherwise never angry) when they are acting as part of a given group - that is, within the processes and relationships that constitute it. This anger might then be described as group, or group-related, anger. However, more needs to be said if the claim that this anger is irreducible to the anger experienced by individual members is to be made out. One could perhaps seek to extend the functionalist argument and claim that phenomenal states are also best explained functionally. Yet, I find it difficult to imagine how this claim could be persuasively developed. As Pettit himself recognizes, functionalist claims that corporate entities have emotions that are relatively autonomous from those of their individual members are generally suspect. It is one thing for states and corporate state institutions to be able to form distinct judgments, beliefs, intentions, and other actiondirecting attitudes by following, to a reasonable extent, whatever steps are prescribed in their constitution. It seems to be quite another for irreducible affective states to be generated in a similar way. In other words, there seems to be more to phenomenal states-say, to the experience of fear or 
anger - than mere questions of organizational structure and function. ${ }^{23}$ Accordingly, it is at least plausible that Andrew Simester, who appears to think that such states are distinctively human (or, at least, animal as opposed to artificial), is correct.

To be sure, some theorists do defend the possibility of irreducibly collective emotions. However, their arguments tend to rest on the dubious premise that emotions can exist without affective experience. Thus, Margaret Gilbert, the most prominent advocate of collective emotions, adopts early on in her argument Martha Nussbaum's claim that some emotion-types may have no necessary phenomenal concomitant, citing the non-conscious fear of death as an example. ${ }^{24}$ Besides the fact that the existence of non-conscious, non-affective emotional states is highly questionable, it is important to note the difference between the claim that every emotional state does not necessarily come with a specific and distinctive affective experience, and the claim that affect can altogether be absent from emotional experience. While the former claim is admittedly plausible, the latter is rather more counter-intuitive. It may well be true that unlike moods, which refer to purer forms of affective experiencethink of free-floating depression, sadness, elation, or euphoria-emotions also have cognitive components, such as being directed at objects and

${ }^{23}$ P Pettit, 'Akrasia, Collective and Individual' in S Stroud and C Tappolet (eds), Weakness of Will and Practical Irrationality (Oxford: Oxford University Press, 2003) 68, 79. One should be careful when assessing the implications of this proposition. Many theorists hold that for an agent to be blameworthy and legitimately blamed this agent must be morally responsible in the sense of being able to respond to reasons. Some further claim that this ability requires the emotional capacity to be moved by moral concerns. It follows, they contend, that affect-less corporate organizations can never be blamed legitimately. See especially S Wolf, 'The Legal and Moral Responsibility of Organizations' in JR Pennock and JW Chapman (eds), Criminal Justice: Nomos XXVII (New York: New York University Press, 1985) 267. This position rests on an account of legitimate blame that we need not accept. Pettit, who implicitly resists it, is in good company in this respect: see eg the literature listed in $n$ 13. Alternatively, let us not forget that, as Pettit himself recognizes and as I discuss further below, irreducible corporate organizations may, derivatively, be moved by the emotions of their constituent members. According to Pettit's account, individual members remain the ones who introduce evaluative propositions for group consideration and who, collectively, decide upon them.

${ }^{24}$ M Gilbert, 'Collective Guilt and Collective Guilt Feelings' (2002) 6 J of Ethics 115, 119-120, citing M Nussbaum, Upheavals of Thought (CUP Cambridge 2001) 61. 
involving beliefs about them. My fear of a dog, for example, does seem to involve a cognitive construal of a number of the dog's features (its salivating maw, its ferocious bark, its running towards me) as frightening. However, it does not follow that the relevant cognitive aspects of emotions can altogether be devoid of affective experience. Such a position seems radically out-of-touch with the phenomenology of emotions, and much current research has sought to discredit it. ${ }^{25}$

Then again, to the extent that affect-free 'emotional states' do exist or, following Nussbaum, that some 'emotions' are best explained in purely cognitive terms - say, as evaluative judgments that ascribe great importance to certain things or persons - it seems more accurate to treat them generically alongside other cognitive states, rather than as part of a distinctive emotional genre. Indeed, insofar as an 'emotion' is best explained as a mere configuration of beliefs or as a cognitive attitude, I see no reason not to label it and treat it as such. To repeat, according to an account such as Pettit's, suitably-constituted states and state institutions can have cognitive states (such as beliefs) and action-directing attitudes (such as intentions) of their own. It is phenomenal states, such as affective states, they cannot experience. ${ }^{26}$

Does this view entail that states cannot claim excuses grounded in their own affective experiences? The conclusion seems to follow, and follow as much in the realm of domestic law as in the realms of

${ }^{25}$ See eg M Stocker, Valuing Emotions (Cambridge: Cambridge University Press, 1996); LC Charland, 'Reconciling Cognitive and Perceptual Theories of Emotions: A Representational Proposal' (1997) 64 Philosophy of Science 555; J Pankseep, Affective Neuroscience (Oxford: Oxford University Press, 1998); P Greenspan, Emotions and Reason: An Inquiry into Emotional Justification (New York: Routledge Chapman and Hall, 1988). For an even more radical argument, advocating a close identification of emotions with feelings: P Goldie, The Emotions: A Philosophical Exploration (Oxford: Oxford University Press, 2000).

${ }^{26}$ Insofar as conative attitudes such as wishing, desiring, longing, or craving have phenomenal components, it may also be that corporate agents cannot have them, or can only have them partially. Pro-attitudes devoid of phenomenal components are more straightforwardly available to corporate agents. In this respect, intentions and other cognitively-defined pro-attitudes are least problematic. I thank Antony Duff for pressing me on this point. 
international law and morality writ large. Note, however, that even if states and corporate state institutions cannot claim affect-based excusesor, more broadly, excuses grounded in their own phenomenal consciousness - they may still be able to claim excuses that are derivative from the phenomenal experiences of their individual members. Remember that, even if the account of group agency on which I am basing my analysis is an account of relatively autonomous group agency, it is still individual group members who supply all its matter and energy. So, for example, it is a state's individual members who introduce information and option-related evaluative propositions for its consideration. Insofar as the information and propositions thus introduced are distorted by, say, the fear experienced by the individuals introducing them, state judgments and intentions formed on their basis may turn out to be mistaken. Arguably, the greater and the more widespread the fear experienced by the members - which, in a liberal democracy, may include not only officials, but a large part of the citizenry - the likelier it is that their affective experience will influence state decision-making and cause corporate errors.

Consider, for example, the effect that the deep and widespread fear of sudden murderous attacks - which exists amongst important segments of Israel's general population and state officials - might have on state decisions. All else being equal, could this fear excuse, at least partially, some of Israel's harshest reactions, as well as some of the unjustified reactions of specific governmental and defense institutions, to events that do not constitute threats but are collectively perceived as such? All else being equal, could the dread of terrorist strikes that prevailed in the US after the events of September 11, 2001, at least partially excuse some of the state's legally and morally wrongful and unjustified responsesincluding indefinite pre-emptive detentions of both adults and children at Guantanamo Bay, official sanction and perpetration of degrading forms of treatment as means of interrogation, as well as unwarranted invasive military campaigns? At one point in his brief discussion of state excuses, Simester seems to open the door to this possibility by qualifying his argument, and recognizing that it might just be possible for states to invoke epistemic mistakes as excuses for wrongdoing. 'Epistemic mistake,' he writes, is 'a quite different type of case.' 27

${ }^{27}$ Simester, 'Necessity, Torture, and the Rule of Law' (n 3) 300. 
Although Simester does not explain this statement any further, one important distinction is readily identifiable. Unlike duress, epistemic mistake is a cognition-based, as opposed to an affect-based, ground of exculpation. If, indeed, states and corporate state bodies can have cognitive abilities, they too may sometimes fall prey to epistemic failures and, thus, are vulnerable to making mistakes. Beyond what Simester recognizes, they may also fall prey to more radical distortions grounded in irresistible ignorance, as well as in other non-belief-based cognitive attitudes. Even more importantly for our immediate purposes, though, what Simester fails to acknowledge is that the factors that can cause state cognitive distortions not only include individual epistemic limitationssuch as misleading or unavailable evidence - and other purely cognitive failings, but also phenomenological distortions experienced by individual members. In other words, when it comes to states and other irreducible corporate agents, cognitive distortions may not always be entirely cognitive. For example, affective distortions of the practical rationality of individual members may sometimes lie at the root of their corporate organization's cognitive failings. In this sense, it might sometimes be possible to speak of states and corporate state institutions that act while being 'blinded by fear' or 'blinded by anger' and then seek to be excused on that ground, with the proviso that the fear or anger in question is the fear or anger of their individual members. The same could also be said of states and state institutions acting in the grip of the (popular) mood of the moment.

Of course, this argument does not amount to a claim that Israel, the US, or any of their institutions should be excused for their unjustified wrongs on the ground of affectively-induced epistemic mistakes. What it does, however, is to elucidate further some key intricacies of cognitive distortion as a conceivable ground of excuse for them.

\section{Some Sui Generis State qua Corporate Excuses?}

These last remarks warrant a parenthetical note of methodological caution. The analysis as I have conducted it so far assumes that commonlyencountered individual excuses constitute the standard against which the 
intelligibility of excusatory claims by group agents should be assessed. In other words, my argumentative strategy has so far been to think of excuses in terms of commonly-encountered individual excuses - such as duress, provocation, and mistake in justification - and ask whether such claims are also available to irreducible group agents. Insofar as these agents have what it takes to claim such excuses - and they may not, as in the case of affective experiences - I see no reason why we should not, at least in principle, recognize their possibility (or so I will continue to assume). Then again, my remarks at the end of the last section highlight the fact that irreducible group agents form a special category of agents. Unlike individual agents, their existence and agency depend on, yet are irreducible to, the existence and agency of other (individual) agents. Doesn't this constitutional difference warrant a distinct, or perhaps more complex, approach to understanding at least some conceivable claims of group excuses? I think it might.

What it means for individuals to act appropriately qua ordinary individuals may differ from what it means for them to act appropriately qua members of a group agent, or so they may think or feel. While full commitment of individual members to the group, its constitutional operation, as well as its rational coherence and integrity over time, may ensure that the group behaves in the fashion of a virtuous agent, various members may sometimes be moved, for good or bad reasons, to act in less than committed ways. They may, for example, temporarily turn their eyes away from the group in order to act fairly, charitably, or humanely qua individuals, or because of affective distractions, or simply because of selfish or biased inclinations. When this happens, the group may not act in the minimally rationally consistent way that we would expect of an agent proper. ${ }^{28}$ Indeed, such lapses may even put the status of the group as an irreducible agent in jeopardy. At the same time, notice that they may not challenge this status to the same extent as more fundamental structural deficiencies may, as we saw, generate failed or quasi-states.

Consider the case of the United States' failure to join the League of Nations in the 1920s. Although its president at the time, Woodrow Wilson,

${ }^{28}$ A minimum of rational coherence and integrity also seems necessary for individual human moral agency, even if the required threshold likely falls well short of perfection. 
led an American charge for the League's creation and ensured that its constitutional covenant - contained in the Treaty of Versailles - would be crafted in a way that assumed US membership and leadership, the US Senate refused to ratify the treaty and, therefore, to join the organization. This senatorial rejection, primarily attributable to the opposition of a number of ideologically uncompromising Republican members, sowed the seeds for the League's collapse, which culminated in its inability to prevent the Axis Powers' aggressions that led to World War II. ${ }^{29}$ Could Wilson, acting in the name of the United States, have claimed an excuse for his state's harmful volte-face by invoking the erratic character of the US's dualist system of reception of international treaty law-which involves negotiation and signature of treaties by the Executive, and ex post facto ratification by Congress? In other words, if a state (or other irreducible group agent) is imperfectly organized in a way that facilitates rational inconsistency of the sort just exemplified, could such a constitutional disorder ground an excuse?

The question is tantalizing since such organizational deficiencies, coupled with individual members' lapses in commitment to group rational integrity, may indeed explain a state's failure to live up to relevant behavioural standards. This kind of explanation may be especially forceful in cases, such as the one just described, where the deficient mode of organization is inherited from the past and is not easily changed, due to constitutional restrictions. Pettit claims that groups that fall prey to such momentary, yet radical failures in rational coherence and integrity can retain their overall status as irreducible agents. They can do so, he argues, insofar as the bulk of their members remain generally disposed to play their part in the integration of the group as an agent proper. Such groups must also 'prove capable of acknowledging and denouncing the failure and, ideally, reforming their behavior in the future - or if not actually achieving reform, at least establishing that the failure is untypical. ${ }^{30} \mathrm{In}$ circumstances in which a group meets these conditions, Pettit speaks of rational unity of 'a second-best sort: a unity that can exist in spite of the

\footnotetext{
${ }^{29}$ See generally JT Knock, To End All Wars: Woodrow Wilson and the Quest for a New World Order (Princeton: Princeton University Press, 1995); RB Henig (ed), The League of Nations (Edinburgh: Oliver and Boyd, 1973).

${ }^{30}$ Pettit, 'Akrasia, Collective and Individual' (n 23 ) 85.
} 
disunity displayed in actual behaviour. ${ }^{31}$ In respect of my League of Nations example, it could be argued that the volte-face at issue was untypical of US behaviour (at the time, at least), and that the US subsequently made significant efforts to impress upon other international actors that it should generally be trusted to live up to its representations and commitments (insofar as it made any). Thus, an exculpatory claim to the effect that, given its entrenched constitutional ordering, the US could understandably fail to act as a rationally unified agent in circumstances like the ones that led to its failure to join the League, is at least imaginable. Claims of this sort could also conceivably be made by more discrete state institutions acting within the national sphere.

When, if at all, these claims should be recognized is a further question. For what are mostly prudential (or strategic) reasons, international law tends to be reluctant to acknowledge states' internal deficiencies as acceptable grounds of exoneration. For example, it is often said that such an acknowledgement would inevitably lead to undue erosion of international regimes of state responsibility. However, there is no absolute moral bar against the invocation of internal deficiencies as exculpatory grounds. To return to the analogy with individual defenses for a moment, criminal law sometimes recognizes that people who perpetrate harmful deeds while having momentarily lost touch with reason might legitimately be able to deny responsibility for these deeds, either fully or partially. Consider, for example, the oft-encountered defenses of automatism and diminished responsibility.

Interestingly, Pettit would likely resist categorizing group claims of momentary constitutional disorder that make reliable decision difficult as sheer denials of responsibility. He prefers to think of the group failures in question in terms of conflicts of 'inner voices' - that is, the voices of different members - that are analogous to conflicts between 'voices of the heart' and 'voices of the head' that give rise to more reasons-based (and responsibility-affirming) individual excuses such as normal cases of duress and provocation. ${ }^{32}$ Of course, this kind of analogy between the

\footnotetext{
${ }^{31}$ ibid 82.

${ }^{32}$ On the distinction between denials of responsibility and more reasons-based excuses, see Gardner, Offences and Defences (n 13) 131-132; RA Duff, Answering for Crime:
} 
excuses-generating 'inner voices' of individuals and groups is bound to be imperfect. The types of conflicting 'inner voices' at play and their role in promoting or impeding agency undoubtedly differ significantly as between groups and individuals. However, argues Pettit, insofar as we conceive of reason as a certain unified sort of pattern, the analogy can be instructive. ${ }^{33}$ Notably, it invites us not to overlook the complex role of reason, broadly understood with all its cognitive and affective components, in group claims such as claims of excuses other than sheer insanity.

Pettit's reluctance to analogize too easily cases of group constitutional disorder and individual denials of responsibility also has the potential to shed contrasting light on the alluring analogy between exculpatory pleas of individual infancy and claims that developing states and state institutions may make in relation to various developmental hiccups. While normal young human infants are only minimally responsive to reason, they progressively acquire a more refined understanding of themselves and their surroundings as they age. The range of actions for which they are basically responsible - in the sense of being able to provide rational explanations for them-tends to increase correspondingly. Thus, many modern juvenile justice systems appropriately strive, with varying degrees of success, to hold children responsible only for wrongdoing for which they are basically responsible in this sense, and to modulate their remedies and sanctions accordingly. ${ }^{34} \mathrm{I}$ say that this approach is appropriate since pleas of human infancy are not claims of conflicting 'inner voices' in Pettit's sense, which may be amenable to appraisal in light of excusatory standards. They are denials of responsibility for alleged wrongdoing (at least in the form in which such wrongdoing is alleged).

Responsibility and Liability in the Criminal Law (Oxford: Hart Publishing, 2007) 284291.

${ }^{33}$ Pettit, 'Akrasia, Collective and Individual' (n 23) 89-93.

${ }^{34}$ On the nature and importance of the distinction between 'being basically responsible' and 'being held responsible,' see J Gardner, 'Hart and Feinberg on Responsibility' in M Kramer, C Grant, B Colburn and A Hatzistavrou (eds), The Legacy of H.L.A. Hart (OUP Oxford 2008) 121. 
States and state institutions may also make exculpatory claims of developmental infancy, yet it is not as clear that all such claims are best explained as sheer denials of responsibility. Consider, for example, the predicament of post-Apartheid South Africa where, within a short period of time, a myriad of people of colour who had previously been excluded joined the civil service, and started implementing the Interim Constitution. Although these new state officials were gradually trained and mentored, and their transitional constitutional framework was progressively fleshed out, individual inconsistencies and mistakes were initially bound to take place, resulting in blunders, slip-ups and, possibly, wrongdoing at the corporate level. While, in such a case, it is also the group's capacity to respond appropriately to reason that is at stake, Pettit teaches us that the developmental deficiencies in question may not obliterate the group's basically responsible agency, and susceptibility to be held responsible and blamed for its wrongful exercise. To repeat, there remains for Pettit a 'second-best' sense of unified, irreducible corporate agency which, in the face of teething problems, rests on the group's members persistent and general commitment to its integration as an irreducibly constituted agent, as well as on the group's ex post reaffirmation and readjustment of this integration. Thus, unlike in cases of individual human infancy, corporate bodies that are initially unable to respond to reason appropriately due to developmental hiccups might still at times appropriately be held responsible and blamed for related wrongdoing. ${ }^{35}$ Then again, it is also conceivable that these groups' blameworthiness-like the blameworthiness of older, more established groups struggling with constitutional disorders - may sometimes be mitigated, when relevant excusatory standards of institutional resilience, due diligence, as well as ex post facto denunciation are met. ${ }^{36}$

\footnotetext{
${ }^{35}$ Note, however, Pettit's subsidiary and fiction-based 'developmental rationale' for holding both children and 'embryonic group agents' responsible and punishing them in some way for harm to which they are merely causally related: it incentivizes them to pull themselves together so as to avoid such harm in the future. Pettit, 'Responsibility Incorporated' (n 17) 198-201.

${ }^{36}$ This point finds reflection in discussions of how the existence of effective "compliance programs" in private corporations may affect how blameworthy they are, and how much they should be punished, for criminal wrongdoing. On this related question: C GómezJara Díez, 'Corporate Culpability as a Limit to the Overcriminalization of Corporate Criminal Liability: The Interplay Between Self-Regulation, Corporate Compliance, and Corporate Citizenship' (2011) 14 New Crim L Rev 78.
} 
Here, I am not denying that some states and state institutions with infant, frail, or limited decision-making structures may sometimes be basically responsible for some specific actions, while not being basically responsible for others. ${ }^{37}$ Indeed, such teetering reality may be especially frequent in infant states with constitutional deficiencies that exceed the mere inability to train officials adequately. In large part, this is because constitutional structures including agency-enabling balances and checks such as the separation of powers, the rule of law, parliamentary democracy, and judicial review take time to develop. As it were, France and the United Kingdom did not emerge from the state of nature overnight, and were likely non-responsible for many harms associated with their evolution. My goal here is simply to point out that there is almost certainly more to the corporate agency story than this, and that the possibility of sui generis corporate excuses, differing from common individual excuses, should not be overlooked. At the same time, the complex nature of these sui generis claims and the magnitude of the philosophical apparatus that would be needed to elucidate them fully prevent me from saying any more here, for fear of losing sight of my initial goal of mapping out the many theoretical puzzles related to state excuses. Then again, I think have said enough to build at least a prima facie case for the intelligibility of group claims of excuses on the ground of constitutional disorder (short of sheer non-responsibility). I would ask readers to keep this possibility in mind when thinking about the constellation of excusatory claims that may be available to irreducible group agents.

\section{The Lack of Valuable Self-Interest Objection to State Excuses}

\footnotetext{
37 The categories of 'quasi-states' and 'weak institutions' are sometimes used to reflect this possibility. On this point, see T Erskine, 'Kicking Bodies and Damning Souls: The Danger of Harming "Innocent" Individuals While Punishing "Delinquent" States' (2010) 24 Ethics \& Intl Affairs 261, 268. As NW Barber argues based on the work of WR Bion in Experiences in Groups (London: Routledge, 1989), constitutional weaknesses can also be exacerbated by various state 'neuroses,' such as excessive reliance on a leader (totalitarian or not) and undue fixation on a perceived threat as a source of group identification and unification. Barber, The Constitutional State (n 1) 117-123.
} 
Another prominent set of objections to the possibility of state qua corporate excuses has both metaphysical and moral aspects, which tend to be run together in argument. According to it, even if we grant that states have much of what it takes to make excuses - for example, that they are normally rational agents that can make errors in cognition and perhaps even undergo some forms of affective experiences - we should still never recognize their excusatory claims. The general thought is that corporate agents like states are purely instrumental creations that have no real interests or subjective values of their own. Insofar as they do-after all, the paradigm of corporate agency explored allows for irreducible group judgments and attitudes about what matters to the group's survival and what is important to the realization its constitutional goals-then such group self-interest and values should never be given weight in law or morality more generally. Corporate agents exist, or should exist, exclusively to promote the interests and values of others - that is, of noninstrumental agents like human beings. Therefore, the objection holds, no recognition should ever be given to their self-interested excusatory claims. No matter what affective pressures they incur, or what mistakes they commit, states and state institutions should never be excused for wrongfully privileging themselves. Nor should they be excused for any tendency they may have to do so. For example, they should never be excused under the heading of duress for acting wrongfully due to what were perceived as overbearing threats to their interests or subjective values. $^{38}$

In my view, the apparent strength of this line of argument comes primarily from its close affinity with the principle of value individualism, according to which the worth of the state (and, indeed, of anything else) must ultimately be appreciated in terms of its contribution to human life and its quality. If, indeed, it is only human interests and values that matter (here, some allowance may also be made for interests of other non-human

${ }^{38}$ The excuse of duress tends to be explained in terms of self-interest. For example, Jeremy Horder writes that 'The agent-specific character of reasons for action in duress is associated with the centrality of the fact that the threat confronts the defendant with having to make a personal sacrifice, or commit wrongdoing.' The personal sacrifice in question, he adds, can be any significant sacrifice of 'self-interest' or, more broadly, of 'one's cherished values.' J Horder, 'Self-Defence, Necessity and Duress: Understanding the Relationship' (1998) 11 Canadian J of L and Jurisprudence 143, 161. 
conscious beings), then there seems to be no residual moral space for the recognition of the so-called interests or subjective values of irreducible corporate agents. One possible rejoinder might be that value individualism does not necessarily commit one to a purely instrumentalist view of corporate agency. If one could demonstrate that corporate agents like states or state institutions are intrinsically valuable as necessary constituents of goods that intrinsically enrich human life, then some limited recognition and protection of 'their interests' - or of their natural tendency to protect their interests - could, perhaps, be warranted (for example, in the form of excusatory concessions for state wrongdoing). Some have recently mounted spirited arguments in favour of the existence and value of groups' irreducible interests along such lines, and it may be that they are onto something. ${ }^{39}$ However, powerful objectionsquestioning the metaphysical soundness of such arguments and the acceptability of their possible moral implications - continue to dominate current debates, and invite great theoretical caution. ${ }^{40}$

${ }^{39}$ In a number of famous essays, Charles Taylor sets the stage for a rejoinder of the type outlined in the text, positing that some intrinsically valuable common goods may necessarily implicate the state. See eg C Taylor, 'Atomism' in Philosophy and the Human Sciences: Philosophical Papers 2 (Cambridge: Cambridge University Press, 1985); C Taylor, 'Cross-Purposes: The Liberal-Communitarian Debate' in NL Rosenblum (ed), Liberalism and the Moral Life (Cambridge, Mass: Harvard University Press, 1989) 159. However, Taylor himself stops short of speaking of valuable state selfinterest. For a recent argument going all the way and defending the existence and value of 'non-aggregative collective interests,' see DG Newman, 'Collective Interests and Collective Rights' (2004) 49 American J of Jurisprudence 127. See also J Waldron, 'The Dignity of Groups' in J Barnard-Naudé, D Cornell \& F du Bois (eds), Acta Juridica 2008 (Cape Town: Juta \& Company, 2009) 66.

${ }^{40}$ See eg Will Kymlicka's forceful counter-argument to Taylor's view of common goods in W Kymlicka, Liberalism, Community and Culture (Oxford: Oxford University Press, 1989). See also M Dan-Cohen, 'Sanctioning Corporations' (2010) 19 J of L and Policy 15. Dan-Cohen's premise is that all deontological constraints on practices of blame and punishment are grounded in 'human dignity.' While this premise is questionable on both conceptual and moral grounds, his overall point that the justification of these practices has to be rethought in light of the primarily instrumental value of corporations must be taken seriously. On the general need for theoretical caution in this area, see further D Rodin, War and Self-Defense (Oxford: Oxford University Press, 2002) 143-144. 
What is perhaps a less metaphysically doubtful and morally hazardous way of challenging the interest objection to corporate excuses is to cast doubt on another assumption that underlies it. I am referring here to the assumption that claims of excuses can be reduced to calls for moral or legal leniency for agents who wrongfully, though understandably, disregard the interests of others in order to protect their own. I believe that this assumption is unwarranted. It is simply untrue that valid excuses can only arise in the context of dilemmas between self-interest and the interests of others, where the wrongdoer is deemed to have stricken a balance between the two that is sufficiently virtuous to block or attenuate inferences of blame. Many excuses have nothing to do with self-interest, so that the question of whether or not corporate entities like states and state bodies have interests of their own is often quite irrelevant to their ability to make such claims legitimately.

It is true that some claims of excuses, such as those relying on sufficient display of courage in the face of coercive threats, may be connected to questions of self-interest. As Aristotle once dramatized it, using the example of the citizen who risks being killed on the battlefield for the sake of his homeland, courage is a virtue of character that tends to arise out of a struggle between personal safety and external considerations, such as collective victory. ${ }^{41}$ However, not all displays of virtue that may yield legitimate claims of excuses have the same structure. For example, loyalty, which the state may invoke in a bid to excuse wrongfully favouring citizens over non-citizens, is a virtue that, at its core, is otherregarding. In my view, a theory of morality that would only account for dilemmas between the pursuit of self-interest and the pursuit of the interests of others, exclusively allowing for excuses in such contexts, would be radically deficient. As the example of loyalty highlights, dilemmas of moral life can also arise between different ways of engaging with pursuits that have others' valuable interests at their heart, and valid claims of excuses might well be made in such contexts as well. Moreover, some claims of excuses have very little, if anything, to do with questions of interests writ large. Think, for example, of claims of epistemic mistake, constitutional disorder, or claims more akin to full or partial denials of

${ }^{41}$ On courage generally and on Aristotle's understanding of it, see D Pears, 'The Anatomy of Courage' (2004) 71 Social Research 1. 
responsibility (insofar as they are appropriately categorized as excuses). Thus, even if one concedes that states, like other corporate bodies, have no valuable interests of their own, state excuses must not necessarily be ruled out as a possibility. The range of available grounds of state excuses may then differ from the range of available grounds of individual excuses, as may the range of available grounds of corporate excuses in general, but this should not be taken to mean that states, or other irreducible corporate entities, may never make valid excuses.

\section{Questioning the Irreducible Corporate Agency Model and Related- Excusatory Claims}

A more sweeping moral objection to state excuses, understood as excuses claimed by states or state institutions qua irreducible corporate agents, denies the very necessity for such excuses in the first place. Such excuses are thought to be unnecessary since practices consisting in holding corporate agents responsible for wrongdoing and, say, blaming and punishing them for it, are morally redundant. According to this line of objection, both the moral and legal regulation of human actions, be they individual or collective, and practices of accountability for wrongdoing can and should be articulated in exclusively individualistic terms. That is, insofar as we understand grounds and practices of moral and legal accountability for wrongdoing in suitably complex and nuanced waysallowing for sufficiently broad accounts of complicitous and joint wrongdoing - the possibility of holding irreducible groups responsible, blaming them, and punishing them really becomes superfluous. ${ }^{42}$ Thus, the question of whether irreducible group agents can invoke excuses turns out to be moot.

One possible rejoinder is as follows: an account of irreducible group agency like Pettit's has the advantage of providing a distinct ground for holding groups such as states and their corporate institutions responsible and blaming them-say, because their actions made harm likely or inevitable - at times when no similar ground is available for

42 Christopher Kutz's argument seems at least partly animated by this idea in his Complicity: Ethics and Law for a Collective Age (Cambridge: Cambridge University Press, 2000) and 'Causeless Complicity' (2007) 1 Crim L and Philosophy 289. 
holding individual contributors responsible and blaming them. This kind of shortfall of individual responsibility may arise when, for example, individual contributors to state action avoid being held responsible and blamed for their deeds owing to reasonable mistakes or ignorance, due care, duress, or other relevant excuses. Practices of state qua irreducible group responsibility may guard against such scenarios, as well as diminish the incentive for people to arrange things so as to increase their likelihood.

Here, one may be tempted to retort that, even if this rejoinder is sound, it is nevertheless self-defeating. Indeed, if the state can be excused for its wrongs when its individual members are excused for their own wrongful contributions, aren't shortfalls of responsibility unavoidable? I believe that this worry is largely unwarranted. First, excusable individual contributions to state action do not necessarily entail excusable state behaviour, and vice-versa. For example, it is not because specific individual state members act mistakenly or under duress that their state or corporate state institution will necessarily act mistakenly. Multiple checks and balances are typically in place to reduce the likelihood of the former automatically translating into the latter. Grounds of responsibility may also be different for the state and its members, such that the excuses of one may have nothing to do with the wrongs of the other.

What is more, in respect of reasons-based excuses such as epistemic mistake or normal cases of duress or provocation, role-based considerations must also be factored in. In law as in morality, excusatory standards often vary according to the roles played by those who claim excuses. ${ }^{43}$ Thus, the standards of excusability applicable to individual state officials, although possibly more stringent than the standards applicable to ordinary people, may be nowhere near as stringent as the standards applicable to given corporate state institutions or, perhaps even more strikingly, to the state in all its grandeur. States are typically designed and built to be outstandingly strong and knowledgeable, in order to solve social problems that individuals and smaller corporate entities acting in uncoordinated ways are unable to solve - such as the securing of social order, safety, trust, and the conditions of societal cooperation. They tend

${ }^{43}$ See generally Gardner, 'The Gist of Excuses' in Offences and Defences (n 13) 121-139, as well as his 'Reply to Critics' 245. 
to have access to multiple and often better sources of information than other social actors (including their members taken individually). They also tend to have greater resources, authority over many more people, and more extensive opportunities for contingency planning and training than other agents. With such attributes come greater responsibilities and greater (arguably, much greater) expectations of virtue, skill, and reasonableness. Insofar as the idea of capacity to do otherwise matters to some excuses, different standards may also be applicable to states and their individual members in this regard. ${ }^{44}$ Therefore, even in situations where all individual state members are excused for their contributions to state wrongdoing, the state and its institutions may well not be. Of course, the possibility of a shortfall of responsibility always remains. However, if I am correct, such shortfalls are likely to be rare.

Now, it might also be possible to resist the shortfall of responsibility argument at a more general level by arguing that the exonerating force of epistemic limitations and other types of pressures inherent in organizational settings is less significant than has traditionally been believed. One salient reason for this skepticism is as follows: insofar as individuals know-or, perhaps, ought to know-that they are participating in the operation of a group decisional framework that may, by its very constitutional design, yield bad or harmful outputs, it is questionable whether they should ever be able to escape consequential responsibility by invoking the irreducibility of these outputs. Alternatively, it may be that these individuals should only ever be entitled to partial excuses that mitigate their blameworthiness for wrongful participation in collective harm, as opposed to negating it altogether. ${ }^{45}$ Of course, this analysis also leaves open the possibility that there may be scenarios in which the conduct of no individual contributor to harmful state action quite amounts to wrongdoing, or only amounts to relatively insignificant wrongdoing. Yet, if the line of argument just outlined is sound, the shortfall of individual responsibility argument may not provide

\footnotetext{
44 cf Horder, Excusing Crime (n 14) chs 3-4.

45 Jeff McMahan makes a forceful argument along such lines in relation to individual soldiers' decisions to fight in unjust wars in Killing in War (Oxford: Oxford University Press, 2009) 137-154.
} 
as forceful a case for holding irreducible group agents responsible as some think it does.

Furthermore, even insofar as the shortfall of responsibility argument provides a compelling case for group responsibility, including the possibility of blame and its cognates, some skeptical minds may still object. They may object that, on any plausible account, conditions for irreducible group responsibility will be so demanding that many states and state institutions such as courts, legislatures, ministerial cabinets, and administrative agencies are unlikely to meet them, or to meet them on any consistent basis. It cannot simply be assumed, they might insist, that states and their institutions are agents capable of being held responsible and blamed in an irreducible sense, like Pettit and others sometimes seem inclined to do. More radically, some might also advance objections to the very metaphysical possibility of irreducible group agency and responsibility, and simply reject accounts such as Pettit's as misguided.

At this point, one should be careful not to throw the baby with the bath water. If, indeed, the shortfall of individual responsibility argument is a valid one, as I think it at least sometimes is, then there will likely remain considerable pressures-grounded in reasons of deterrence, justice, expressiveness and symbolism, as well as various other pragmatic concerns - for practices of group accountability for collectively facilitated harm that cannot be blamed, in whole or in part, on individual wrongdoers. Thus, there may sometimes be good reasons to treat the state-even if only understood as a socio-legal or functional grouping without irreducible moral agency-as if it could intelligibly and legitimately be held responsible, blamed, and perhaps even punished, like a fully-fledged responsible agent. In other words, we may sometimes be justified in erecting fictions (or, more loosely put, figurative accounts) of state responsibility and blameworthiness. This may be the case when, for example, such holdings would have significant expressive value - think of situations in which there is mass popular support for, or acquiescence to, unjustified official wrongdoing. Such fictions may also lead to critical reforms in state members' behaviour and contribute to forestalling future misconduct. Such a consequentialist way of thinking about state responsibility for wrongdoing could conceivably complement, or perhaps even replace, more robust models such as Pettit's. Therefore, we must also 
spend some time analyzing the implications of this second paradigm for the possibility of state excuses.

\section{From Realism to Pragmatic Fiction}

\section{The General Problem}

In both law and morality, groups are sometimes treated as agents even when they are not, and held responsible, blamed, and punished for conduct and outcomes that are only fictionally 'theirs. ${ }^{46}$ A case in point is that of regimes of corporate criminal liability which rely on doctrines of identification or vicarious responsibility to hold corporations accountable and blame them for some of the wrongs and harms perpetrated by their members, either individually, aggregatively, or jointly. Many such regimes are premised on the imputation to the corporation of a package, comprising some designated individuals' conduct (including their acts and mental states), that amounts, or is relevantly related to, wrongdoing. Other such regimes involve the sheer attribution of individuals' blameworthiness to the corporation. ${ }^{47}$ The question for us is this: insofar as the imputed conduct or blameworthiness is that of individual human beings who are at least partially excused for their own deeds, can their individual excuses ever limit or affect that for which the corporation can legitimately be blamed and punished?

Indeed, the structure of regimes like the ones just mentioned does not necessarily preclude the concurrent imputation to the group of related individual excuses - with all their components, be they cognitive,

${ }^{46}$ The most comprehensive discussion of legal fictions remains L Fuller, Legal Fictions (Stanford: Stanford University Press, 1967). Moral fictions are the subject of an entire school of moral theory often referred to as 'fictionalism.' While many of the questions addressed in the moral fictionalism debate are deeper and only indirectly related to the topic addressed here, a useful overview can be found in M Eklund, 'Fictionalism', The Stanford Encyclopedia of Philosophy (Spring edn, 2009) $<$ http://plato.stanford.edu/archives/spr2009/entries/fictionalism/>. See also J Feinberg, 'Collective Responsibility' (1968) $65 \mathrm{~J}$ of Philosophy 674, who treats collective responsibility as an inherently vicarious form of responsibility.

${ }^{47}$ For a good survey, see Cane, Responsibility in Law and Morality (n 12) 148-158. See also H Kelsen, General Theory of Law and State (New Brunswick, NJ: Transaction Publishers, 2006) 96-109. 
affective, etc. Insofar as state institutions such as local governments or other public bodies are targets of moral blame or criminal liability in this imputed way, such a structural observation also seems to apply. So does it to cases in which the state as a whole may, in similar ways, be blamed and threatened with sanctions, be it in the context of constitutional law, international law, or morality more generally. That is, the excusatory claims of individuals whose conduct or alleged blameworthiness is at stake may conceivably also be imputed to the state and its institutions by means of fictions.

But should individual excuses be imputed to groups in such ways? As I indicated at the end of the last section, theorists who think of collective responsibility, collective blame, and collective punishment as fictions tend to justify associated practices in pragmatic terms. Christopher Kutz, for example, argues that such practices can be justified as means of changing collective behaviour for the better, or as means of expressing symbolically more significant criticism for the joint perpetration of harm (than if criticism was solely aimed at individual contributors). ${ }^{48}$ Now, insofar as the attribution of individual excuses to a group can at least partially exonerate it and, consequently, pre-empt the realization of such valuable reformative and symbolic ends, it is easy to see why pragmatist theorists are reluctant to admit that such attribution is ever warranted. ${ }^{49}$ Attribution of individual excuses to groups, their thought goes, would threaten to undermine the very rationale for blaming and punishing them for the acts of individuals.

The mistake that should not be made here is to assume that the reasons invoked to justify blaming and punishing groups by means of fictions always trump countervailing reasons. Admittedly, there will at times be strong reasons in favour of group accountability, group blame, and even group punishment for harmful wrongdoing. However, there may also be significant competing reasons that can defeat these strong reasons.

\footnotetext{
${ }^{48}$ Kutz, Complicity: Ethics and Law for a Collective Age (n 42) 191-197. Note that the idea of shortfall of individual responsibility tends to underlie discussions of justifications of the second kind.

${ }^{49}$ Thus, in ibid 3, Kutz speaks about pleas for excuse in primarily individualistic terms.
} 
For example, blaming and punishing groups may stigmatize innocent individual members and cause them to suffer unfairly. The problem of unfair dispersion of group blame and punishment has plagued theorists of collective responsibility for years, and there does not seem to be any easy cure. To be sure, some think that, in light of the seriousness of the problem, we should simply refrain from blaming and punishing groupsand perhaps especially large and complex groupings like states and state institutions. ${ }^{50}$ Then again, justice - and, more broadly, morality - may not demand such a radical conclusion, and attribution to groups of relevant excuses, in tandem with wrongdoing, might form part of a more nuanced position that gives due consideration to reasons for blaming and punishing groups as well as to reasons against it, such as unfair dispersion concerns. Attribution of individual excuses to groups may also serve important expressive ends. For example, it may provide a meaningful acknowledgement that, in certain circumstances, there are duties which individual group members should not be blamed, or should not suffer, for failing to discharge either on their own or together. What is more, imputation of excuses to groups might matter outside the context of straightforward blame and punishment. At times, such imputation may suitably mitigate crippling compensatory obligations that befall group members for the erratic and generally detrimental conduct of a few individuals acting, in the group's name, under, say, duress or epistemic misapprehensions. ${ }^{51}$ Or in the case of the declaration of an unjust war, attribution of excuses to the declaring state may modulate its members' overall liability to harmful self-defensive action. Of course, all these

\footnotetext{
${ }^{50}$ See eg DF Thompson, 'Criminal Responsibility in Government' in JR Pennock and JW Chapman (eds), Criminal Justice: Nomos XXVII (New York: New York University Press, 1985) 201, 212-213. At 224, Thompson adds that 'the problem of dispersion of punishment is even more serious in government than in other organizations. Not only does the punishment fall on citizens who, like shareholders or employees of corporations, had nothing to do with the crime and may not be able to do anything about similar crimes in the future, but it also often falls most heavily on those citizens who have the least opportunity to do anything about such crimes.'

${ }^{51}$ Such mitigation may be especially important when the target group does not have the organizational capacity to redistribute the costs appropriately between group members. On this point, see A Pasternak, 'The Distributive Effect of Collective Punishment' in T Isaacs and R Vernon (eds), Accountability for Collective Wrongdoing (Cambridge: Cambridge University Press, 2011) 210, 230.
} 
claims are controversial and arguments beyond what I can provide here would be needed to vindicate them, insofar as they can be. That said, I offer them as plausible candidates of areas in which fictions of group excuses may play an important role and as provocations for further theoretical scrutiny.

One of the fiercest opponents of (legal) fictions, Jeremy Bentham, used to deride them as 'lies' that 'may be applied to a good purpose, as well as to a bad one: in giving support to a useful rule or institution, as well as to a pernicious one. ${ }^{52}$ For Bentham, the only appropriate response to this ambivalent and rather unpredictable character of fictions was to get rid of them altogether. However, since fictions of group responsibility can serve important ends, this remedy seems drastic. A more discerning position may be to insist that such fictions must always be justified, in the sense of being deployed for undefeated reasons. As suggested above, it is at least plausible that imputation of individual excuses to groups, alongside other elements comprised in the package imputed to them through doctrines of identification or vicarious responsibility, might on occasion help ensure that practices of group-and, more to the point, state-blame, punishment, and their cognates remain so justified.

The point also applies if groups such as states can be irreducible agents and one asks whether the emotions, moods, interests, and the like, of their individual members may ever be imputed to them by means of fiction-in ways that could contribute to grounding claims of group excuses. Here again, the issue is one of justification. Yet, in the case of the state, many are reluctant to concede even the very possibility of such justified fictions given what they perceive as the slipperiness of the concession. The state is a purely instrumental creature, they claim, and given its role and position in society, it should embody the epitome of knowledgeability, self-control, and fortitude. As I claimed in the last section, there is certainly some truth to this suggestion. But should states - however we understand them - really always be held to standards of perfection in reasonableness, skill, and virtue, such that any talk of state excuses and related talk of state emotions, moods, and interests are really

52 J Bentham, The Works of Jeremy Bentham, vol VII (J Bowring ed, Edinburgh: William Tait, 1843) 287. 
moot $a b$ initio? Throughout this chapter, I hinted in various ways at my discomfort with this radical suggestion. In the next section, I, at last, tackle upfront its most prominent incarnation.

\section{The State as an Inexcusable Beacon of Virtue?}

A challenging group of objections take aim at the suggestion that states may legitimately be afforded excuses in situations where their 'special relationship' with, and instrumental value to, their human subjects are at issue. The thought seems to be that, given the nature of the state as an entity whose every function and action should be instrumentally tailored to the well-being of its subjects, such situations are a common place. They are a common place and give rise to expectations of state virtue that are so exacting as to create a virtually insurmountable barrier to the legitimate recognition of state excuses. These objections primarily take issue with the possibility of domestic state excuses, understood either according to the irreducibility paradigm or the fiction paradigm, given the deep and inevitable interplay between a state's actions and its subjects at the domestic level. Still, international variants are also conceivable.

A first such objection rests on the fact that not only does the modern state typically have great resources and opportunities for action, it also characteristically claims a preeminent social role for itself as wielder of supreme and legitimate authority over a territory and its occupants. The objection is that, given such attributes, the state should not only seek to be, but be expected to be, a model of virtue for all those who live under it, work on its behalf, or otherwise relevantly cross its path. Indeed, what standing would it have to guide them, hold them responsible, and sometimes even blame and punish them were it not to live up to what it preaches and more? Besides, wouldn't excusing the state for unjustified wrongdoing risk creating erroneous perceptions amongst individual state officials and ordinary subjects that no more is actually expected of them? Such moral concerns, and there are no doubt many related others, are undoubtedly deserving of serious consideration. For some, though, they are so salient as to require holding the state to a standard of virtuous perfection in its dealings with its subjects. In such contexts, the thought goes, even if states can face exigent circumstances and, say, undergo debilitating affective experiences - real or fictionally attributed - they must always be expected to tower above them, with complete 
equanimity. ${ }^{53}$ Therefore, there ought to be no excusatory concessions to state frailty.

Simester emphasizes a distinct, yet related objection, when he argues that 'it is not open for the State, or its officials, to prefer the interests of one person to another, since the State is not entitled to be closer to one person than another. It is equidistant, impartial to all. ${ }^{54}$ Here, the underlying assumption seems to be that, insofar as states have valuable interests and personal values, they are expected never to act on them in their relationships with their subjects. Insofar as they do not have such interests and values, yet one embraces a conception of morality that admits of primarily other-regarding dilemmas, such as dilemmas of loyalty, states are also expected to refrain from engaging in them, once again in the context of their relationships with their subjects. Accordingly, even if valid excuses may sometimes be available to individual wrongdoers in relevantly similar circumstances, such excuses should never be recognized when invoked by or in the name of the state.

Part of the apparent strength of this last objection derives, in my view, from the powerful liberal idea that states should administer justice impartially and impersonally. Were states not to behave in this way, liberals argue, the very idea of state justice would be severely undermined. I am sympathetic to this position, which I take to be quite uncontroversial. However, the administration of justice does not exhaust the activities of the modern state. States also seek to thwart the spread of diseases and risks of natural disasters, they make administrative decisions in matters of taxation, immigration, healthcare and national security, they wage war and engage in all sorts of other pursuits that are not strictly tied to the administration of justice. In the context of these further pursuits, could it not sometimes be excusable for states, state institutions, as well as officials acting in their name and behalf to be partial on account of relevant allegiances? For example, whereas it may be morally wrong, all things considered, to expel illegal immigrants who have resided and integrated in a state, as well as contributed to it for a long time, is it really

\footnotetext{
${ }^{53}$ This objection was first suggested to me, in spirit, by John Gardner.

${ }^{54}$ Simester, 'Necessity, Torture, and the Rule of Law' (n 3) 302.
} 
always inexcusable for the state to proceed given significant popular and political pressures stemming from the citizenry?

Some, like Simester, seem to believe that state partiality is indefensible at the domestic level, and that states should be expected to adopt a perfectly impartial and impersonal standpoint in their dealings with their subjects (or, at least, their citizens). Some strict cosmopolitan moral theorists endorse an even more far-reaching version of this view, arguing for stringent duties of justice, respect, and beneficence owed to all human beings regardless of territorial jurisdiction, social ties, and political affiliations. These are theorists for whom the objection to state excuses considered here would likely extend to key international dimensions of states' conduct, such as those impinging on the human rights of people who are outside their jurisdiction and are not their subjects. For example, such theorists would likely resist the grant of any excuses to states declaring unjust wars to protect their citizens. This position stands in stark contrast with that of various particularist and pluralist communitarians of various stripes who readily reject as unrealistic and unreasonable any such premise of perfect state impartiality. ${ }^{55}$

Who is right? I do not intend to delve at length into this last debate, nor into the issue of which precise standards of virtue should apply to states. My intention is rather to draw the reader's attention to an oftneglected, yet plausible defense of official public attitudes which, despite being conducive to partiality and lesser equanimity, may be consistent with a proper, instrumental account of the role and value of the state. Opponents of state excuses who insist on state impartiality and virtuous perfection at all times, tend to overlook the strength of such arguments.

Consider the gap that sometimes exists, at both state and non-state levels, between what I will call the morality of motives and the morality of actions. For example, take the case of the army officer whose hotheadedness sometimes leads her to be less than impartial, treat many of

\footnotetext{
${ }^{55}$ For a thought-provoking discussion of the tension between these two kinds of outlooks, see R Rao, Third World Protest: Between Home and the World (Oxford: Oxford University Press, 2010). On the specific question of excuses and reasonable partiality in the context of war, see S Lazar, 'The Responsibility Dilemma for Killing in War: A Review Essay’ (2010) 38 Philosophy and Public Affairs 180, 197-198.
} 
her subordinates harshly, and deal with enemy combatants mercilessly. All things considered, her hot-headed actions may not always be justified. However, for army officers in many important roles, such hot-headedness is a morally desirable attitude. For example, we would not want them to be such coldfish that they are unable to motivate their troops. Hot-headedness might also be a condition of their success in battle. In other words, hotheadedness may be instrumental to the realization of some of the legitimate state purposes that army officers exist to serve qua officials whose conduct is imputable to the state. I believe that this point also holds with respect to a wide-range of individual and, possibly, irreducible corporate attitudes that are crucial to the fulfilment of state functions, yet can sometimes drive a wedge between morally acceptable thinking about actions and morally acceptable actions. Think of risk-averseness, carefulness in planning, dedication to people's welfare and responsiveness to their needs, efficiency-mindedness, and so forth.

Conflicts between morally desirable attitudes and right action are a recurring feature of moral life for both ordinary individuals and states. As Robert Merrihew Adams pointedly remarks, such conflicts can often be tragic:

Are there some circumstances in which it is best, for example, in the true morality of motives, to be unable to bring oneself to sacrifice the happiness of a friend when an important duty obliges one, in the true morality of actions, to do so? I don't know. But if there are, the interests involved, on both sides, are far from trivial, and the seriousness of both moralities can be maintained. If one fails to perform an important duty, one ought, seriously, to feel guilty; but one could not do one's duty in such a case without having a motivation of which one ought, seriously, to be ashamed. The situation presents a tragic inevitability of moral disgrace. ${ }^{56}$

I take part of the point of the previous passage to be that some breaches of duty - that is, some wrongs - may not be justified, all things considered, even when perpetrated out of friendship. However, in some contexts, the willingness to stand up for a friend even in the face of conflicting duty

${ }^{56}$ R Merrihew Adams, 'Motive Utilitarianism' (1976) 73 J of Philosophy 467, 478. 
may still be reasonable. If not necessarily admirable, it may well be understandable. Common claims of excuses take hold in such instances of wrongdoing that stem from understandable motivations. ${ }^{57}$ When appropriate standards of virtue are met, such claims may well be legitimately recognized. Insofar as they are grounded in motivations that are instrumental to legitimate state functions, they may also be appropriately imputed to the state in tandem with other aspects of individual behaviour with which it is identified. Of course, if states and state institutions do not have personal values, interests, or conscious phenomenal experiences of their own qua irreducible group agents, not all types of motivations that may lead to valid individual excuses may be available to them under that specific understanding of state responsibility. Yet, at the very least, it seems to me that states and state institutions so understood may have reasonable cognitive attitudes or inclinations that are defensible as instrumental to their proper functions. Such attitudes may play a significant part in shaping their motivations for action and, sometimes, open the door to valid claims of state excuses for wrongdoing.

Again, I am not denying that many excusatory standards to be applied to states and state institutions qua irreducible agents, or to officials whose conduct is imputed to the state, should, as a matter of course, be demanding. This conclusion seems to follow from the special social position of the state vis-à-vis its subjects and its typically greater resources, authority, and general opportunities for action. Yet, I remain unconvinced that such features necessarily translate into excusatory standards of virtuous perfection for states and that, unlike for individuals, no excusatory recognition should ever be given to their understandable distortions in judgment, either at the domestic or international level. After all, states are collectives of individuals and, therefore, it seems that our expectations of them must at least partly depend on expectations that we have of these individuals acting together.

${ }^{57}$ This is one of a number of important insights to be found in C Finkelstein, 'Excuses and Dispositions in Criminal Law' (2002) 6 Buffalo Crim L Rev 317. Unfortunately, the holistic consequentialist conception of excuses that she elaborates is, in my view, excessively thin, narrow, and unqualified. 
To be sure, it seems to me that we could plausibly conceive of different excusatory standards of virtue applicable to different realms and types of state activity, with the most stringent perhaps applicable to state activities that impinge most severely on basic human rights. We could also plausibly conceive of different excusatory standards applicable to the state's domestic as opposed to international incarnations, to the state as a whole as opposed to discrete state institutions, to different such institutions, to states and state institutions at different stages of development, to state institutions as opposed to private corporations or individuals discharging state functions, and so forth. Likewise, even if the state should be expected to be expertly knowledgeable about certain things, excusatory standards for epistemic mistakes may well vary between domains of activity. Indeed, in some such domains, liberal restrictions on what the state should know, and seek to know, may themselves be quite stringent. As discussed in previous sections, different kinds of excusatory grounds such as complete or partial lack of basic responsibility, the modulating potential of group excuses for concerns associated with group blame and punishment, and valuable symbolism, may also warrant the recognition of at least some state excuses. None of these grounds of excuse are virtue-driven and, like in the case of epistemic mistake and constitutional disorder, they have nothing to do with the permissibility of state partiality. Thus, the possibility of legitimate excusatory concessions to the state may well not be as unthinkable as many believe.

\section{Conclusion}

In this chapter, I have sought to highlight central theoretical puzzles related to the question of whether state claims of excuses may ever be intelligible and, if so, legitimately recognized. The arc of my argument has been that even if the range of excuses available to the state does not overlap neatly with excuses available to ordinary individuals, excuses may indeed be morally available to states. For some, my argument may raise the spectre of murderous, torturing, or otherwise wicked states being offered unconscionable paths to absolution. I disagree. What my argument does, or at least attempts to do, is to expose the challenge of state excuses for what it is, so that it must be addressed in all its complexity and not simply wished away. Of course, much work remains to be done to determine the appropriate grounds, precise internal structure, and apposite 
standards of virtue and skill for specific state excuses, in specific contexts. A more refined understanding of the state, its functions, its susceptibility to holdings of moral and legal responsibility, blame, and punishment, perhaps developed in comparison with other social actors such as private corporations, would likely assist with this multifaceted task. So might closer scrutiny of the concepts of blame and punishment-individual and collective - and their relationship with excuses, as well as of my generic categorization as 'excuses' of various exculpatory claims that may in fact be saliently different. It also remains an open question whether all excuses morally available to states should be recognized by the law or whether, in some cases, pragmatic concerns or concerns of political morality constitute insuperable obstacles.

Once again, my aim here was merely to map out various issues that appear salient to me. For all I know, when all is said and done, the realm of legitimate state excuses may turn out to be very limited indeed. Still, I hope to have said enough in this chapter to convince you that, in respect of many relevant facets of this debate, the jury is still out. The jury also remains out in respect of many aspects of the broader topic of group excuses considered as a class, as well as on the question of how, if at all, state (and, more broadly, corporate) organizational structures may affect the personal excuses of individuals operating under the them. The theoretical road ahead is rich and challenging, and I certainly hope that, in the near future, many more will be travelling it with me. 